\title{
ELIMINATION OF FIG MOSAIC FROM FIG SHOOT-TIP CULTURES BY THERMOTHERAPY
}

R. Gella

Unidad de Fruticultura

Servicio de Investigacion Agraria

Diputacion General de Aragon

Apdo. 727. 50080 Zaragoza

Spain

\author{
J.A. Marin \\ Unidad de Pomologia \\ Estacion Experimental "Aula Dei" \\ Consejo Superior de Investigaciones Cientificas \\ Apdo. 202. 50080 Zaragoza \\ Spain
}

M. Lopez Corrales and F. Toribio

Servicio de Investigacion y Desarrollo Tecnologico

Junta de Extremadura. Finca "La Orden"

Apdo.22.06080 Badajoz

Spain

Additional index words: Ficus carica L., shoot tip, mosaic virus, thermotherapy

Abstract

Apical buds $(0.5-0.7 \mathrm{~cm})$ of fig tree (Ficus carica L.) of cvs. "Urdana", "Napolitana"

"Tiberio" and "Villalba" with evident mosaic symptoms were cultured in MP solid medium (Pontikis and Melas, 1986) and then subjected to an alternating, high temperature regime with $16 \mathrm{~h}$ light $(5.000 \mathrm{lux})$ at $37^{\circ} \mathrm{C}$ followed by $8 \mathrm{~h}$ dark at $34^{\circ} \mathrm{C}$. These in vitro techniques resulted in fig plants with no external symptoms of fig-mosaic disease after a year of pot cultivation in the greenhouse. Since $F$. carica is tolerant to high temperature treatments, the in vitro thermotherapy with alternating temperature is an appropriate method to eliminate the fig mosaic. This method allows production of a large number of treated shoot tips with high survival and regeneration rates. Indexing showed an absence of fig mosaic disease in all the plants obtained by this treatment.

\section{$\underline{1 . \text { Introduction }}$}

The fig tree (Ficus carica L.) is a typical species of Mediterranean countries. In the last years, as a result of the current crisis in agriculture and the increasing demand for diversity in agricultural products by consumers, this species has been considered as a potential alternative fruit crop for some agricultural areas in Spain. However, establishing new commercial orchards requires the study of different aspects, like plant material, methods of propagation, pruning, fertilization, fresh fruit conservation, etc. which has already been initiated (Toribio, 1993). Another of these aspects could be the sanitary selection, because figs are prone to fig mosaic, an endemic disease that is widely distributed in most varieties and countries where figs are cultivated. This disease, first described by Condit and Horne in 1933, mainly affects leaves, young branches and fruits. The symptoms are expressed as very evident mosaic lesions on the leaves. These lesions can also appear as diffuse areas of chlorosis, often with well-defined margins. In addition, this disease induces distortions in leaf shape and reductions in leaf area (Casalicchio, 1964). Because there are no field treatments, the most effective strategy is the production of healthy plants to be planted in new commercial orchards. Moreover, the production of healthy plants also allows the study of how the fig mosaic affects production, fruit quality and conservation.

Although the success depends on many factors (Nemeth, 1986), thermotherapy - high temperature treatments $\left(35-37^{\circ} \mathrm{C}\right)$ for certain periods of time - has been applied in many species against viruses in woody plants. For this reason, different authors have used an in 
vitro system to obtain healthy plants of species that are sensitive to high temperatures, like cherry (Snir and Stein, 1985; Deogratias et al., 1989; Gella et al., 1995) or peach (Stein et al., 1991).

Healthy fig plants were obtained by traditional thermotherapy, but there were plant regeneration problems (Martelli, 1966; Savio, 1978). Later on, Muriithi et al., (1982) tried to produce mosaic-free plants by promoting the elongation of apices developed in vitro under traditional thermotherapy, without micropropagating the material obtained. Pontikis and Melas (1986) micropropagated fig shoots, but they did not study the sanitary status.

In the present study, fig shoot-cultures infected with fig-mosaic were established with the objective of obtaining mosaic-free figs by in vitro therapy. This study included in vitro culture of shoot-tips developed during the treatment, micropropagation of regenerated shoots, rooting, plant acclimatization and indexing.

\section{Materials and methods}

\subsection{Plants}

Fig tree plants with evident mosaic symptoms of cvs. "Urdana", "Napolitana", "Tiberio" and "Villalba" were propagated by hardwood cuttings and were grown in pots under greenhouse conditions. These plants were utilized as source plants for in vitro propagation.

\subsection{In vitro propagation and heat therapy}

Apical buds $(0,5-0,7 \mathrm{~cm})$ were sterilized in a solution of sodium hypochlorite ( 5 g.l-1 available $\mathrm{Cl}$ ) and $0,01 \%$ Tween-20 for 20 minutes and rinsed 4 times in sterile distilled water.

Buds were cultured in the solid medium (MP) described by Pontikis and Melas (1986). Shoot cultures were maintained in a controlled environment chamber at $22 \pm 2{ }^{\circ} \mathrm{C}$ with a light intensity of 2.500-3.000 lux and a long day photoperiod ( $16 \mathrm{~h}$ light/ $8 \mathrm{~h}$ dark). Shoots were subcultured every 4 weeks and transferred to fresh medium every 4 weeks for 8 months.

Heat treatments were given to the plant material in tissue culture: microcuttings (1,5-2 $\mathrm{cm}$ ) with 2 or 3 axilar and devoid of terminal apex were subjected to the following alternating temperature regime: $16 \mathrm{~h}$ light $(5.000$ lux $)$ at $37^{\circ} \mathrm{C}$ followed by $8 \mathrm{~h}$ dark at $34^{\circ} \mathrm{C}$.

The heat treatments were finished when shoots started to display high temperature effects (chlorotic leaves, low shoot growth, necrotic tips, etc.). At this moment, the tips (1-2 $\mathrm{mm})$ developed under these treatments were excised and in-vitro cultured on MP medium.

\subsection{Rooting and acclimatization}

In vitro and ex vitro rooting ability of fig (Ficus carica L.) microcuttings was previously studied in our laboratory with the objective of establishing the most effective method (Lopez Corrales and Gella, 1994). Ex vitro rooting was carried out in the greenhouse: microcuttings $(2-2,5 \mathrm{~cm})$ were placed directly into Jiffypots with the substrate in absence of hormonal solution. Immediately afterwards, they were covered with a plastic tunnel, which was opened daily during increasing periods of time. After the development of roots ( 4 weeks), the plants were transplanted into bigger pots containing peat and vermiculite $(1: 1)$. 


\subsection{Indexing}

The presence or absence of fig mosaic in plants obtained after in vitro therapy was quantified by an indexing protocol developed for this species (Lopez Corrales, 1996). This protocol consists in chip budding in virus-free indicator plants, which were obtained from seeds of cv. "Tiberio" and propagated in vitro. Temperature and two successive cutting-backs were the two most important factors that had to be optimized to obtain at least $60 \%$ of symptom transmission ratio into indicator plants.

The indexing blocks consisted of: 5 indicator plants inoculated with a bark piece from only one thermotreated plant. The positive controls were 5 indicator plants by each three treatments inoculated with a bark piece of fig mosaic infected plants. The negative controls consisted of 5 indicator plants, inoculated with their bark, by each 3 treatments.

\section{$\underline{\text { 3. Results }}$}

\subsection{In vitro culture and heat therapy}

Fig tree plants were easily cultivated in vitro, although some phenolic compounds appeared on the base of the explants during the establishment of the culture.

Fifteen days after heat therapy treatments, the shoots of the different cultivars showed good aspects as leaves of intense green colour, shoot multiplication and development of axilar buds were observed. Afterwards, the shoots became chlorotic and the growth rate decreased rapidly.

All cultivars appeared to be tolerant to heat therapy, and there was no difference in tolerance between cultivars. In general, shoots with bad aspects and little vigor are more sensitive to thermotherapy.

The number of treatment days was large for all cultivars.

At the end of the heat treatments, shoot-tips (1-2 mm) excised from fig tissue culture were of a pale green colour, but when they started to grow the leaves exhibited a deep green colour and great survival rates during the first subculture (Table 1)

High percentage of ex vitro rooting and acclimatization was obtained and the plants were of a high quality and normal appearance.

None of the regenerated plants had shown symptoms of fig mosaic after a year in pots in greenhouse.

\subsection{Indexing}

The indexing protocol showed an absence of the fig mosaic in all the plants obtained by thermotherapy.

\section{Discussion}

This study demonstrates that in vitro cultivated fig shoots are tolerant to prolonged heat treatments. Also, in vitro culture of tips excised after thermotherapy is a good method for plant regeneration due to their micro propagation ability.

This method gave better results than those utilized by Martelli (1966) and Savio (1978). It is an easier method than the traditional thermotherapy, with a very high survival rate of shoot-cultures. Also, in vitro culture allows for the control of certain factors (like temperature, lighting and humidity) that affects the success of plant regeneration. Barba et al. (1992) regenerated plums and peach plants after thermotherapy by in vitro culture of tips, but they obtained low rooting and decreased healthy plant rates.

In vitro thermotherapy treatments with alternating temperature regime $(16 \mathrm{~h}$ light at $37^{\circ} \mathrm{C}$ followed by $8 \mathrm{~h}$ dark at $34^{\circ} \mathrm{C}$ ) was an effective method and resulted in elimination of fig mosaic and greater survival rates of shoot-cultures. This temperature regime was successfully applied to shoot-tip cultures of PNRSV-infected cherries (Gella et al., 1995). 
Alternating temperatures were used for inactivation of PNRSV in cultured tissue of Prunus persica L. (Stein et al., 1991). However, in other species (Musa acuminata) a constantly high temperature regime was more effective against other viruses (Wu and $\mathrm{Su}$, 1991).

In vitro thermotherapy permits acceleration of the process of obtaining healthy plants because treatments can be carried out all year round and many plants can be treated at the same time, thus increasing the chances of survival of healthy clones. Also, the indexing protocol allows for the screening of the presence of the fig mosaic in plants obtained by thermotherapy.

\section{References}

Barba, M., L. Martino and F. Lauretti, 1992. Comparison of different methods to produce virus-free stone fruits. Acta Horticulturae 309: 385-392.

Casalicchio, G., 1964. Ricerche sul cosidetto mosaico del fico. Annali della Experimentzione Agraria 18(3-4): 453-474.

Deogratias, J.M. F. Dosba and A. Lutz, 1989. Eradication of prune dwarf virus, prunus necrotic ring spot virus and apple chlorotic leaf spot in sweet cherries by combination of chemotherapy, thermotherapy and in vitro culture. Canadian Journal Plant Pathology 11:337-342.

Gella R., M. Lopez Corrales and M.T. Clares, 1995. Eliminacion del "Prunus Necrotic Ring Spot Virus" en cerezo mediante termoterapia in vitro. VI Congreso de la Sociedad Espanola de Ciencias Horticolas. Barcelona 25-27 Abril de 1995.

Lopez Corrales, M. and R. Gella, 1994. Enraizamiento "in vitro" e "in vivo" de higuera (Ficus carica L.) prapagada "in vitro". XXVI Jornadas de Estudio. A.I.D.A. Propagacion vegetal: El reto de las nuevas tecnicas frente a los problemas actuales. Zaragoza. ITEA. 15. Volumen Extra 129-137.

Lopez Corrales, M., 1996. Deteccion y eliminacion del mosaico de la higuera (Ficus carica L.): Aplicacion de tecnicas de cultivo in vitro. Tesis Doctoral. Escuela Tecnica Superior de Ingenieros Agronomos. Universidad Politecnica de Madrid.

Martelli, G.P., 1966. Termoterapia delle virosi. Nuovi orientamenti. L'Italia Agricola 103: 513-528.

Muriithi, L.M., T.S. Rangan and B.H. Waite, 1982. In vitro propagation of fig through shoot tip culture. HortScience 17: 86-87.

Nemeth, M., 1986. Virus, mycoplasma and rickettsia diseases of fruit trees. The Netherlands and Hungary: Martinus Nijhoff.

Pontikis, C.A. and P. Melas, 1986. Micropropagation of Ficus carica L. HortScience 21(1): 153.

Savio, A. 1978. Contribution a l'amelloration sanitaire de l'espece figuier. CTIFL Documents 59(4): 135-138.

Snir, Y. and A. Stein, 1985. In vitro detection and elimination of prunus necrotic ring spot virus in sweet cherry (Prunus avium). Rivista della Ortoflorofrutticoltora Italiana 69(3): 191-194.

Stein, A., S. Spiegel, G. Faingersh and S. Levy, 1991. Responses of micropropaged peach cultivars to thermotherapy for elimination of prunus necrotic ring spot virus. Annals of Applied Biology 119: 265-271.

Toribio, F., 1993. El cultivo de la higuera en Extremadura. Hortofruticultura 12: 51-55.

Wu, R.Y. and H.J. Su, 1991. Regeneration of healthy banana plantlets from banana bunchy top virus-infected tissues cultured at high temperature. Plant Pathology 40(1): 4-7. 
Table 1 - Tips obtained by in vitro thermotherapy and survival

\begin{tabular}{lccc}
\hline Cultivar & Heat-treatment days & Number of tips excised & Number of survival tips \\
\hline Urdana & 24 & 36 & 33 \\
Napolitana & 33 & 15 & 12 \\
Napolitana & 36 & 6 & 6 \\
Napolitana & 40 & 27 & 22 \\
Tiberio & 36 & 30 & 24 \\
Tiberio & 36 & 30 & 27 \\
Villalba & 30 & 40 & 39 \\
Villalba & 42 & 15 & 15 \\
\hline
\end{tabular}

